International Journal of Social Science and Economic Research

ISSN: 2455-8834

Volume:06, Issue:01 "January 2021"

\title{
THE CRITICAL STATUS QUO OF HIGHER EDUCATION IN INDIA- THE WAY FORWARD?
}

“.... educator himself needs educating”- Karl Marx, 1845

\author{
Maria Aishwarya.B \\ Assistant Professor of Sociology, Stella Maris College, Chennai, TN, India \& PhD Research Scholar, \\ Sociology, Christ University, Bengaluru, Karnataka, India \\ DOI: 10.46609/IJSSER.2021.v06i01.005 URL: https://doi.org/10.46609/IJSSER.2021.v06i01.005
}

\begin{abstract}
Contemporary India has been witnessing an unprecedented expansion in the number of higher educational institutions since the wave of liberalization, privatization and globalization (LPG). There is also an observed trend of proportionate distribution in the Gross Enrolment Ratio (GER) in both private and public institutions. The huge proliferation of higher educational institutions has indeed compromised the quality, reliability, flexibility, accountability and transparency parameters in higher education management. The market-led commercialization of education and lack of increased nodal surveillance of higher educational institutions in India at frequent intervals of time has culminated into a wide-spread systemic imbalance subsumed within the dynamics of socio-political power negotiations, capitalist fervour and increasing rates of intellectual labour attrition in both colleges and universities in India. This paper is a revisit into the systemic imbalances through reclaiming the roots of quality education by using a multistakeholder approach. A survey with multiple stake-holders (students, teachers and parents of students in higher education) as a research technique with a concluding summary is adopted to critically understand the varied educational interventions for promoting quality and inclusivity in higher education. It throws light on the diverse and effective means of establishing progressive interventions in educational policy and praxis.
\end{abstract}

Keywords: Higher Education, Stake-holder, Policy, Praxis

\section{Introduction}

The wave of liberalization, privatization and globalization in 1990s transformed the economic landscape and diversified the scenario of higher education in India. It opened up avenues in the field of education with the genesis of new educational institutions driven by private sector initiatives. The massive outgrowth of educational institutions to meet the growing educational 


\section{International Journal of Social Science and Economic Research}

ISSN: $2455-8834$

Volume:06, Issue:01 "January 2021"

demands, increased autonomy, decline in public funding and lack of public policies in education describes how prospects and crises in Indian higher education converge at this point for a discourse. There is a steady out-flow of graduates from higher educational institutions every year.

According to November 2019 Brookings India report titled 'Reviving Higher Education in India' indicates the four-fold increase in the number of higher educational institutions since 2001. The All India Survey on Higher Education (AISHE) (2018-2019) reports the Gross Enrolment Ratio (GER) as $26.3 \%$. The attributing factor to the steady sweep in GER is India's rapid globalization. It has significant outcomes in all socio-economic and cultural spheres though its impact is not evenly distributed across the states and spheres of activity.

However, the target of Ministry of Human Resource and Development (MHRD) of GER is 32\% by 2022. The US based think tank Brookings Institution claims that despite the steady rise in GER, Indian students go abroad for postgraduate programmes showing a low rate of postgraduate enrolment in India. Hence, in today's modern knowledge-economy that has emerged with the retreat of tradition, there is an immediate need to re-visit the higher education sector.

\subsection{Situating the Context of the Research Problem: The existing status-quo of Higher Education Sector in India}

The Scheme of Higher Education Statistics and Public Information System (HESPIS) conducts the survey on Higher Educational Institutions in India instituted by the XII five-year plan, MHRD with different stake-holders as its members. The All India Survey on Higher Education (AISHE) plays an instrumental role in the collection of data on higher education in order to reflect the complete picture of higher education in the country.

The following statistics is listed on the AISHE portal for the year 2018-2019, indicates 993 Universities, 39931 Colleges and 10725 Stand Alone Institutions in India. The higher educational institutions in India are classified into three broad categories namely University and University level institutions that are empowered to award degree mandated by some Act of Parliament or State Legislature; affiliated colleges and institutions which are not empowered to provide degree in its own name and stand-alone institutions that do not award degree and run only diploma level programmes. The AISHE report highlights that highest number of students

enrolled are at the undergraduate level in India. The top six states with the highest student enrolment are Uttar Pradesh, Maharashtra, Tamil Nadu, West Bengal, Rajasthan and Karnataka. However, the top six states with the highest number of educational institutions are Uttar Pradesh, Maharashtra, Karnataka, Rajasthan, Andhra Pradesh and Tamil Nadu. 


\section{International Journal of Social Science and Economic Research}

ISSN: $2455-8834$

Volume:06, Issue:01 "January 2021"

India confronted with the growing rate of educational institutions since 1990s was challenged with the immediate need of reconfiguring its educational quality landscapes by integrating the premise of 'value for money' in order to achieve total quality assurance. Several quality assurance frameworks in India have emerged to deflect criticism of non-accountability of the multiple stake-holders in the higher education institutions and to uphold the quality standards of education in India. With the increase in graduates there is an inverse proportion of redundant labour force emerging every year due to obsolete skills and 'arm-chair', 'babysitting' (Perlmutter,2004) functions of academic professionals in higher educational institutions in India.

Currently, three bodies namely National Assessment and Accreditation Council (NAAC); National Board of Accreditation, All India Council of Technical Education and Accreditation Board evaluate quality assurance and accredits institutions in India. These bodies accredit institutions of higher education, programmes in engineering and agricultural institutions.

Under the aegis of nodal agencies like University Grants Commission (UGC), All India Council for Technical Education (AICTE), Council for Industrial and Scientific Research (CSIR), Department of Biotechnology (DBT) research support and grants-in-aid is available for research endeavours. The Government of India's allocation for education sector in 2019- 2020 is Rs. $94,853.63$ crores.

\subsection{Higher Education in India today: A Critical Appraisal}

India's higher education experienced a steady evolution from traditionalist structures of knowledge dissemination by hegemonical systems of cultural homogeneity and Brahminical orthodoxy rooted in the Gurukul System of Education. It is also important to highlight its positive functions operating as an ideal type of Guru- Shishya discourse with manifestations of the Gurukul ethos namely hard work, austerity and character building. However, it is antithetical to inclusive education and is founded on the grand narrative of caste elitism. The modern higher education today outgrew these hegemonical traditional caste structures and has entered into a dialogue with trans-nationalism. On a more critical account, Indian higher education is engulfed with grappling dimensions of increasing transnational student mobility for postgraduate courses to the Foreign countries, high intellectual labour attrition, technological penetration, digital divide and student migratory flows. The undue romanticization of foreign players in our educational markets to achieve capitalist demands has led to the dearth of expertise in the indigenous institutes of higher education in India. The decisive power mongering for acquiring positions of administrative control by the internal administrative force and faculty-stakeholders of higher education has indeed collapsed the quality, reliability, transparency, accountability and value parameters of Indian higher education despite the steady rise in its quantity. 
International Journal of Social Science and Economic Research

ISSN: 2455-8834

Volume:06, Issue:01 "January 2021"

\subsection{Higher Education, Social Reproduction of Inequalities and Social Justice:}

Rawls argues that social justice requires the equal distribution of 'all social primary goods, liberty and opportunity, income and wealth'. However, Rawl's theory also reinforces the perspective that the idea of reward for merit presupposes the rewarding for those with preexisting advantages thereby countering the idea of social justice. Higher Educational institutions today are camouflaged by social reproduction of inequalities. The urgent need of the hour is to deconstruct the social reproduction of inequalities in higher education through progressive interventions.

The nature of access to educational resources has today become a function of market led commercialization of education as a commodity; traditional structures of hierarchy; lack of quality assurance and evaluation in higher education institutions; micro-political structures; moral policing; pedagogy of teaching and learning processes in higher education institutions are critical issues requiring interventions forms the context and content of the research question of this study. Social reproduction of such inequalities within higher education indicates an intergenerational transmission of structural inequalities generated within conventional hierarchical structures of higher education through perpetuation of traditional educational practices that needs an immediate revisit to create progressive institutions of higher education.

\subsection{Multi-Stakeholder Approach: Re-visiting management of Higher Education in India}

Williamson's specific investment (1975) and Aoki's cognitive assets (2010) are theoretical concepts that can be integrated to provide a framework of governance in higher education institutions. Specific in vestment refers to the formation of different types of capital by the higher educational institutions such as human, financial, social and knowledge capital. Cognitive assets are the teachers and students who act as agents in establishing the specific investment. It is critical to reiterate that generation of social capital and establishment of financial capital has become the major secondary missions of colleges and universities in order to sustain in the higher educational landscapes. A higher educational institution cannot function in isolation as a single-entity and requires the organic interdependence of all stake-holders thereby conceptualizing the model of multiple stake-holder governance. The fiduciary duties and obligations of performance and accountability is a joint responsibility of all the stakeholders namely students, teachers, parents. The multiplicity of actors' in this model holds them legitimately responsible in the welfare of their colleges and universities. (Sacconi,2008) Emulating Rosseau's social contract, the stakeholders enter into a social contract with each other in maintaining the governance and control of the institutions. Higher education plays an instrumental role in making the endowments of capabilities and resource allocation functionally available for all the stake-holders to execute the plans ofaction. 


\section{Methods of research inquiry: Research questions and Methods}

The major research question of this article is situated in the following context of how the declining quality of Indian higher educational institutions be addressed today in contemporary times of systemic imbalance through educational interventions. The author used survey as a research tool to collect data from multiple stakeholders about various key pointers that can be integrated as interventions to deconstruct the rigidity of conventional norms of higher educational institutions that limit innovation and flexibility.

\subsection{Research Question and Objectives of the Study:}

\section{Research Question:}

1.What are the varied educational interventions for promoting quality and inclusivity in Higher Education?

\section{Objective of the Study:}

1.To examine the varied interventions preferred by the multiple stake-holders in higher education for promoting quality and inclusivity.

\subsection{Methodology:}

This research article is a descriptive study. It uses convenience sampling which is a nonprobability sampling method. A Scientific inquiry is used in selecting the type of sampling and the results produces limited generalization not limiting the scope of reliability. Both primary and secondary data is collected in this study. It is an empirical study conducted using a sample survey.

\section{Survey Data Analysis and Discussion: An Overview}

An online survey was circulated to $\mathrm{PhD}$ resource scholars, academic teaching professionals in higher education and parents of students studying in higher education using convenience sampling. Around 20 questions on alternative, niche modalities of educational interventions were asked taking into consideration the larger context of the need for interventions for a positive change in higher educational institutions. The 66 respondents drawn from institutes of higher education, faculty stake-holders and parents in Bangalore and Chennai responded to the questions. The following is a summary analysis of the results of the majority view. The analysis and discussion section are titled as 'Deconstructing Social Reproduction of Inequalities in Higher Education through interventions' 
International Journal of Social Science and Economic Research

ISSN: 2455-8834

Volume:06, Issue:01 "January 2021"

\subsection{Deconstructing Social Reproduction of Inequalities in Higher Education through interventions:}

1.Around $72.7 \%$ of the respondents recommend institutionalizing flipped classrooms in all institutions.

This shows acceptance of stakeholders to novel styles of teaching-learning process. It indicates the importance of a paradigmatic shift from conventional techniques of higher education rooted within the framework of hierarchy and a one-way flow of teaching-learning process to alternative classroom models such as flipped classrooms that embark on educational sustainability.

2.Around $95.5 \%$ affirmatively responded that vocational education/ skilling to be made a mandatory component.

This indicates the need to strongly integrate praxis within our curriculum designs for achieving full-fledged employability and life skills.

3. Around $77.3 \%$ recommend language learning as a requirement for the completion of a course at the higher educational level.

This response signals the need to strengthen regional diversities of our country as language is viewed as a channel to achieve ethnic integration at the intra- community and inter-community levels.

4.Around $69.7 \%$ recommend a Socialist model (de-privatizing) higher education in India.

This is the first step towards universalization of educational standards in India and bridging the gaps between indigenous and elitist universities in India.

5.Around $80.3 \%$ and $77.3 \%$ recommended integrating intellectual minorities (ADHD, Dyslexia) in mainstream higher educational institutions and provisioning of free education for gender minorities (women and transgenders).

This indicates the need to legally institute inclusive higher educational policies in India with an inclusive gender dimension. Such a policy will strongly deconstruct all forms of sexism and ableism in higher education.

6.Around $84.8 \%$ strikingly recommended the entry of Foreign players in education through collaborations and mergers. 


\section{International Journal of Social Science and Economic Research}

ISSN: $2455-8834$

Volume:06, Issue:01 "January 2021"

This indicates that trans-nationalization of Indian higher education is favoured as a way to negotiate with structures of inequity in order to re- configure educational opportunities and optimization through a central state-led higher education collaboration/ merger policy with foreign players in the education sector.

\section{Around 53\% recommended $\mathrm{PhD}$ as a mandatory qualification for teaching positions.}

This indicates that teaching and research is on a continuum. The requirement of a $\mathrm{PhD}$ for a teaching position is preferred. This is a dominant narrative that opens to several discourses on quality and prioritization of degrees? (Rayan,2019).

8.Around $78.8 \%$ recommended a system of cross-subsidy (where affluent through their fee payment fund the free education of less privileged in the society).

In an exclusionary climate aggravated by capitalism, the system of cross-subsidy may encourage conceptualizing education sector on the plane of social entrepreneurship paradigms that strongly synthesize both social and economic value into a single operational framework. A Socialist model of education through a cross-subsidy can contribute to strong deconstruction of social inequalities of classism. Also, it is crucial to note that around $78.8 \%$ felt that the current system of higher education in India subscribes to elitism (means and resources enable acquiring of degrees).

9.Around $77.3 \%$ encouraged decentralized governance of higher education through a multiple stake-holder approach (parents, teachers and students) with decision making powers to hire, fire, budget allocation and curriculum design.

This indicates a strong need to shift from traditionalist structures of hierarchical policies into a more egalitarian governance with participatory accountability and transparency.

10.Around 54.5\% recommended a four-day work curriculum with three days as holidays for students; $68.2 \%$ recommended integration of open-book examinations; $51.5 \%$ recommended continuation of bans on mobile phone usage in higher education institutions in India.

Around 57.6\% recommended recruitment of teaching professionals in higher education through a selection board like UPSC, SSB etc.

This indicates that there is a need to constantly restructure pedagogical practices and employment practices to enhance inclusivity and quality. With education largely digitalized in the wake of COVID 19, the question for reflection is the post-COVID 19 scenario of higher education in India. 


\section{International Journal of Social Science and Economic Research}

ISSN: $2455-8834$

Volume:06, Issue:01 "January 2021"

From the discussion, it is highlighted that there is an immediate need to integrate several novel and collaborative teaching-learning pedagogical practices to classrooms and institutionalize inclusive policies for all. There is a responsibility on the part of all stake-holders to periodically appraise its efficiency for establishing progressive educational institutions.

\section{Conclusive Suggestions and Remarks:}

The following is a short conclusion to highlight other critical challenges faced in higher educational institutions today as a closing note to this paper.

Ageism is rooted firmly in our higher education institutions manifested with hierarchical notions of power, authority and control in academic dynamics. The assertion is on deconstructing traditionalist practices of academic paternalism within higher educational institutions. Such cultures can be effectively transformed into collaborative niche networks where senior professors mentor the entry-level and mid-level academic professionals creating a vibrant exchange of knowledge and establishing intellectual discourses through structured programmes at national and regional levels. Such age-based generational exchanges will bring a gamut of experiences, wisdom, creativity and innovation distinct to the levels of age, seniority and experiences.

Proletarianization of academic professionals under academic capitalism compromises the rigor and quality of teaching and research in India. The emphasis is on how certain norms have led to mobility of scholars seeking academic teaching positions in countries abroad or exiting higher educational institutions to alternative career options. All these are 'other' factors that also contribute to the decline in the quality of teaching- learning in Indian higher educational institutions and requires an in-depth study.

\section{References}

[1] Sacconi, L. (n.d.). A multi-stakeholder and a complementary-cognitive-asset approach to the governance of universities: Theory and Empirics. 1-24.

[2] Rayan, P. (2019, October 19). Question of Quality. The Hindu. (Retrieved on 16.10.2020)

[3] Rawls J. (2005), A Theory of Justice, Harvard University Press, ISBN-13: 978-0674017726

[4] Aoki M. (2010), Corporations in Evolving Diversity - Cognition, Governance, and Institutional Rules, Oxford Scholarship Online, Print ISBN-13: 978-0-19-921853-0.

[5] Perlmutter, D. (2004, November 8). Doctoral Student, Scholar, Baby Sitter? The Chronicle of Higher Education.

[6] Annual Status of Higher Education of State's and UTs in India, CII publications,2019 
International Journal of Social Science and Economic Research

ISSN: 2455-8834

Volume:06, Issue:01 "January 2021"

[7] All India Survey on Higher Education (2018-2019), MHRD publications,2019

[8] Reviving Higher Education in India, Brookings publication,2019 